\title{
Surveying abundance and stand type associations of Formica aquilonia and $F$. lugubris (Hymenoptera: Formicidae) nest mounds over an extensive area: Trialing a novel method
}

\author{
KERRY M. BORKIN ${ }^{1}$, Ron W. SUMMERS ${ }^{2}$ and LEN THOMAS ${ }^{3}$ \\ ${ }^{1}$ Landcare Research, P.O. Box 69, Lincoln, South Island, New Zealand; e-mail: k.borkin@clear.net.nz \\ ${ }^{2}$ Royal Society for the Protection of Birds, Etive House, Beechwood Park, Inverness, IV2 3BW, UK; \\ e-mail: ron.summers@rspb.org.uk \\ ${ }^{3}$ Centre for Research into Ecological and Environmental Modeling, The Observatory, University of St Andrews, KY16 9LZ, UK; \\ e-mail: len@mcs.st-and.ac.uk
}

Key words. Hymenoptera, Formicidae, distance sampling, Formica, line transect, old-growth, Pinus sylvestris, Scotland

\begin{abstract}
Red wood ants are ecologically important members of woodland communities, and some species are of conservation concern. They occur commonly only in certain habitats in Britain, but there is limited knowledge of their numbers and distribution. This study provided baseline information at a key locality (Abernethy Forest, $37 \mathrm{~km}^{2}$ ) in the central Highlands of Scotland and trialed a new method of surveying red wood ant density and stand type associations: a distance sampling line transect survey of nests. This method is efficient because it allows an observer to quickly survey a large area either side of transect lines, without having to assume that all nests are detected. Instead, data collected on the distance of nests from the line are used to estimate probability of detection and the effective transect width, using the free software "Distance". Surveys took place in August and September 2003 along a total of $71.2 \mathrm{~km}$ of parallel, equally-spaced transects. One hundred and forty-four red wood ant nests were located, comprising $89 \mathrm{~F}$. aquilonia (Yarrow, 1955) and 55 F. lugubris (Zetterstedt, 1838) nests. Estimated densities were 1.13 nests per hectare (95\% CI $0.74-1.73$ ) for $F$. aquilonia and 0.83 nests per hectare (95\% CI $0.32-2.17)$ for $F$. lugubris. These translated to total estimated nest numbers of 4,200 (95\% CI 2,700-6,400) and 3,100 (95\% CI 1,200-8,100), respectively, for the whole forest. Indices of stand selection indicated that $F$. aquilonia had some positive association with old-growth and $F$. lugubris with younger stands (stem exclusion stage). No nests were found in areas that had been clear-felled, and ploughed and planted in the 1970s-1990s. The pattern of stand type association and hence distribution of $F$. aquilonia and $F$. lugubris may be due to the differing ability to disperse ( $F$. lugubris is the faster disperser) and compete (F. aquilonia is competitively superior). We recommend using line transect sampling for extensive surveys of ants that construct nest mounds to estimate abundance and stand type association.
\end{abstract}

\section{INTRODUCTION}

Red wood ants play an important role in the ecology of woodland ecosystems by virtue of their large numbers and biomass. Their depredation on defoliating insects benefits trees (Karhu \& Neuvonen, 1998) and shrubs (Atlegrim, 2005), and is sufficient to cause shifts in relative abundance of different insect guilds, such as higher densities of aphids and leaf miners, which are not preyed upon (Fowler \& MacGarvin, 1985). Other insects form symbiotic relationships with ants, including myrmecophilous beetles (Päivinen et al., 2004). Ant distribution may also determine where birds feed through competition for common food, and nest through avoidance of ants (Haemig, 1992, 1999).

In the northern pinewoods of Europe, red wood ants are the most prominent group of ants, though in Britain, there is concern for the status of some species, including Formica aquilonia (Yarrow 1955), which is nationally scarce (Anon., 1999; Hughes, 2005). In Scotland, several red wood ant species inhabit ancient native pinewoods, itself a habitat of high conservation status (Anon., 1995). The ancient native Scots pine Pinus sylvestris (Linnaeus, 1753) forests of Abernethy, Glenmore and Rothiemur- chus in the central Highlands of Scotland are thought to be a stronghold for F. lugubris (Zetterstedt, 1838) and $F$. aquilonia (Hughes, 2005). Despite the ecological importance of red wood ants (Gösswald, 1989) and the conservation concern for some species and their habitat, little is known about the status of red wood ant populations in Britain and elsewhere in Europe, high-lighting the need for more research into population trends and habitat requirements (Hughes, 2005; Mabelis, 2007; Dekoninck et al., 2010).

The domed nest mounds of red wood ants are conspicuous; some can be over a metre high, and are therefore amenable for surveying. Most past survey designs involved mapping individual nests (Breen, 1979; Domisch et al., 2005; Kilpeläinen et al., 2008), though there is a limit to the area over which this can be achieved. An alternative method that has been used for leaf-cutting ants (Sossai et al., 2005) is to survey all nests in a sample of long, rectangular plots (a form of plot sampling, Borchers et al., 2002), although again this involves an exhaustive search over a defined area. In this study, we trialed an alternate method of sampling: a line transect survey (Buckland et al., 2001). Line transects are one form of a wider group of methods collectively referred to 


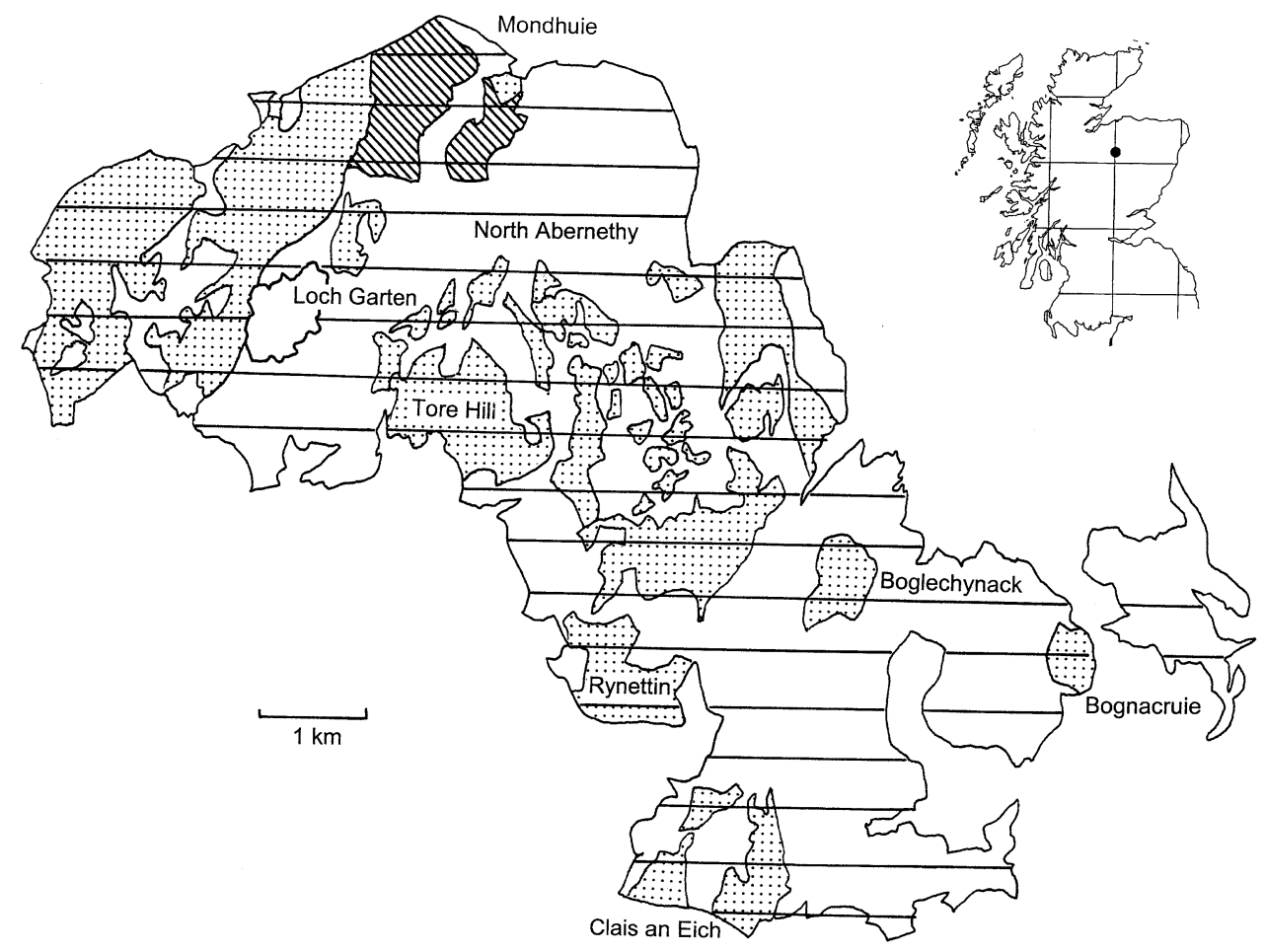

Fig. 1. Abernethy Forest showing the locations of the east-west running parallel transects. Inset - the location of Abernethy Forest in Scotland. Stipple areas indicate post 1930 plantations, and hatched areas were clear-felled during 1997 to 2001.

as distance sampling (Buckland et al., 2001); the methods are used routinely to estimate population size and density of mammals and birds, but not insects. Although mapping all nests in a study area is clearly the gold standard, it is extremely labour intensive and hence rarely possible in practice for large areas of interest. Line transect surveys are more efficient than both mapping and plot sampling approaches because there is no need to exhaustively search an area to ensure that no nests are missed. Instead, observers can move relatively quickly along a set of systematic or randomly placed transect lines, recording the distance to all mounds detected either side of the line, and this information is used during analysis to estimate the detection probability or, equivalently, effective transect width. We provide the first assessment of the numbers and distribution of nest mounds of red wood ants in Abernethy Forest, holding the largest remnant of ancient native pinewood in Scotland (Mason et al., 2004). This method also allowed us to determine associations with stand types. The survey focused on the two commoner species: $F$. aquilonia and $F$. lugubris. $F$. aquilonia is a polygynous species (many queens in one colony) and polydomous (colonies with cooperative nests) (Rosengren \& Pamilo, 1983). It is generally associated with large old forests (Punttila, 1996). By contrast, F. lugubris is a monogynous (a single queen in a nest) and monodomous species generally associated with younger forest stands (Punttila, 1996).

\section{STUDY AREA AND METHODS}

Abernethy Forest $\left(57^{\circ} 15^{\prime} \mathrm{N}, 3^{\circ} 40^{\prime} \mathrm{W}\right)$ lies within Strathspey on the northern slopes of the Cairngorm Mountains, in the cen- tral Highlands of Scotland, 200-500 m above sea level. The stand types within the native pinewood were old open woodland, high-crown woodland and wooded bogs. The forest also had plantation woodland, largely planted after 1930, comprising pole-stage, thicket and pre-thicket. Almost all the trees were Scots pine, whilst the shrub layer comprised juniper Juniperus communis (Linnaeus, 1753), heather Calluna vulgaris (Linnaeus, 1753), bilberry Vaccinium myrtillus (Linnaeus, 1753) and cowberry V. vitis-idaea (Linnaeus, 1753) (Summers et al., 1997).

Ant mounds were surveyed between 22 August and 9 September 2003 using a line transect protocol (Buckland et al., 2001). The single observer (KMB) traversed seventeen parallel transects, running east-west across the forest and $500 \mathrm{~m}$ apart, and totalling $71.2 \mathrm{~km}$ within $37.2 \mathrm{~km}^{2}$ of woodland (Fig. 1). Visibility was good on all 13 days of the survey. A sighting compass and Global Positioning System were used to maintain direction along transects. Once a mound was located, its bearing and radial distance from the transect was measured. This allowed calculation of the perpendicular distance from the transect. The size (width at the base and height) of each nest, as seen from the transect, was measured, so that any differences in detectability due to nest size could be examined. There were no cases of partially connected mounds, so all could be regarded as separate mounds. When the transect line was left to measure a mound, no other mounds were searched for until returning to the line. The stand types in which the mounds occurred were also noted. Different stand types were initially given descriptive categories, but were later combined into four functional stand types of woodland development: stand initiation, stem exclusion, understorey re-initiation and old-growth (Oliver \& Larson, 1996) (Table 1). Areas without trees, including clearfells, remained as a separate category. A sample of five ants was collected from each nest mound and stored dry for later identification (Collingwood, 1979). 
TABLE 1. Stand type categories used in this survey at Abernethy Forest, and average (means or medians) characteristics of the Scots pines (from Summers et al., 1997, 2008) and major shrubs (from Parlane et al., 2006).

\begin{tabular}{lccccccc}
\hline $\begin{array}{l}\text { Descriptive } \\
\text { category }\end{array}$ & $\begin{array}{c}\text { Tree } \\
\text { height }(\mathrm{m})\end{array}$ & $\begin{array}{c}\text { Diameter at breast } \\
\text { height }(\mathrm{cm})\end{array}$ & $\begin{array}{c}\text { Age } \\
\text { (years) }\end{array}$ & $\begin{array}{c}\text { Density (pine } \\
\text { stems per ha) }\end{array}$ & $\begin{array}{c}\text { Percent cover } \\
\text { of heather }\end{array}$ & $\begin{array}{c}\text { Percent cover } \\
\text { of bilberry }\end{array}$ & $\begin{array}{c}\text { Functional } \\
\text { category }\end{array}$ \\
\hline Young pre-thicket & 2 & 3 & 20 & 1730 & 89 & 1 & $\begin{array}{c}\text { Stand initiation } \\
\text { Stand initiation } \\
\text { Pre-thicket }\end{array}$ \\
Thicket & 5 & 10 & 36 & 540 & 87 & 1 & Stem exclusion \\
Pole stage & 15 & 14 & 42 & $>2000$ & 0 & 1 & Understorey reinitiation \\
High crown & 19 & 28 & 67 & 570 & 24 & 31 & Old-growth \\
Old open woodland & 15 & 54 & 120 & 320 & 28 & 40 & Old-growth \\
Wooded bog & 5 & 19 & 149 & 160 & 46 & 28 & Old-growth \\
\hline
\end{tabular}

Estimation of density and population size from resulting data was performed using the software Distance, version 6.0 release 2 (Thomas et al., 2010). Preliminary detection function models were fitted, and the data were truncated (ignored beyond a set distance) so that probability of detection at the truncation distance was approximately 0.15 , as recommended by Buckland et al. (2001). As a check, we also investigated the effect of using other truncation distances. Various detection function models were then fitted, and the model with lowest Akaike's information criterion (AIC) value was selected. Candidate detection function models had either half-normal or hazard rate key functions with cosine or simple polynomial series adjustments, and also included ant species, stand type (the four categories) and nest size (half width, as seen from the transect, multiplied by height, i.e. approximate area visible from a side view) as covariates affecting the scale parameter of the key function (Marques et al., 2004). The final selected detection function model was then used in conjunction with the encounter rate (number of nests per km line length surveyed) to estimate density by ant species. Variance was estimated using estimator $\mathrm{O} 2$ of Fewster et al. (2009) for encounter rate variance, which gives a more reliable and usually lower estimate for systematic parallel lines than the standard method (Fewster et al., 2009).

To quantify stand type associations for each species, Jacobs' selection index (Jacobs, 1974) was calculated by stand type category. The index $(D)$ was derived from the proportion of stand type available $(p)$ relative to all stand types, and the proportion of the species observed within that stand type $(r): D=$ $(r-p) /(r+p-2 r p)$. Values can potentially range between 1 (full association) and -1 (full avoidance). It was likely that the detection of mounds varied among stand types because it was easier to see below the crowns of larger trees than smaller ones. Therefore, in this comparison, the data were truncated so that only those nests within $20 \mathrm{~m}$ of the transect were selected. Confidence intervals on the selection indices were calculated using a nonparametric bootstrap, resampling transect lines with replacement 1000 times. This analysis was performed using customwritten code in the statistical software R (R Development Core Team, 2010).

\section{RESULTS}

One hundred and forty-four nest mounds of red wood ants were located along the transects. These comprised 89 $F$. aquilonia mounds and 55 F. lugubris (Fig. 2). The mean height of $F$. aquilonia mounds was $44 \mathrm{~cm}$ (range $15-110 \mathrm{~cm}$ ) and the mean width $96 \mathrm{~cm}$ (range 24-200 $\mathrm{cm})$. The dimensions of $F$. lugubris mounds were similar: the mean height was $46 \mathrm{~cm}$ (range 13-99 $\mathrm{cm}$ ) and mean width $95 \mathrm{~cm}$ (range 27-188 cm). However, mound height varied significantly amongst stand types, being highest for both species in stem exclusion stands $(57$ and $52 \mathrm{~cm}$ for $F$. aquilonia and $F$. lugubris, respectively), and shortest in old-growth stands (40 and $35 \mathrm{~cm}$ for $F$. aquilonia and $F$. lugubris, respectively) $(F=3.59, P=0.017$ for $F$. aquilonia and $F=3.05, P=0.037$ for $F$. lugubris). Nevertheless, as the apparent side view area for the two species was practically the same, we anticipated that the detectability of the mounds would be similar in the detection function modeling.

The distribution of distances of detected nests from the transect line showed a spike at small distances, coupled with long right tail: the median distance was $5 \mathrm{~m}$ but the mean was $9 \mathrm{~m}$ and the maximum $72 \mathrm{~m}$. The selected truncation distance was $4 \mathrm{~m}$, leaving 66 observations, and at this truncation, the AIC best-detection function was a half-normal model with no adjustments or covariates (Fig. 3). The goodness of fit test indicated a satisfactory model (Kolmogorov-Smirnov test, $D_{n}=0.10, P=0.52$ ). The effective half-width strip was $2.4 \mathrm{~m}$ (CV 10.5\%). This provided a density estimate of 1.13 mounds per hectare (95\% CI 0.74-1.73) for F. aquilonia and 0.83 (95\% CI $0.32-2.17)$ for $F$. lugubris. These density estimates translated to total numbers of $4,200 \quad(95 \%$ CI 2,700-6,400) and 3,100 (95\% CI 1,200-8,100) mounds, respectively, for the whole forest (Table 2 ).

To check the importance of the truncation point, we undertook confirmatory analyses at truncation distances of 2, 10, 20 and $25 \mathrm{~m}$, and found that density estimates

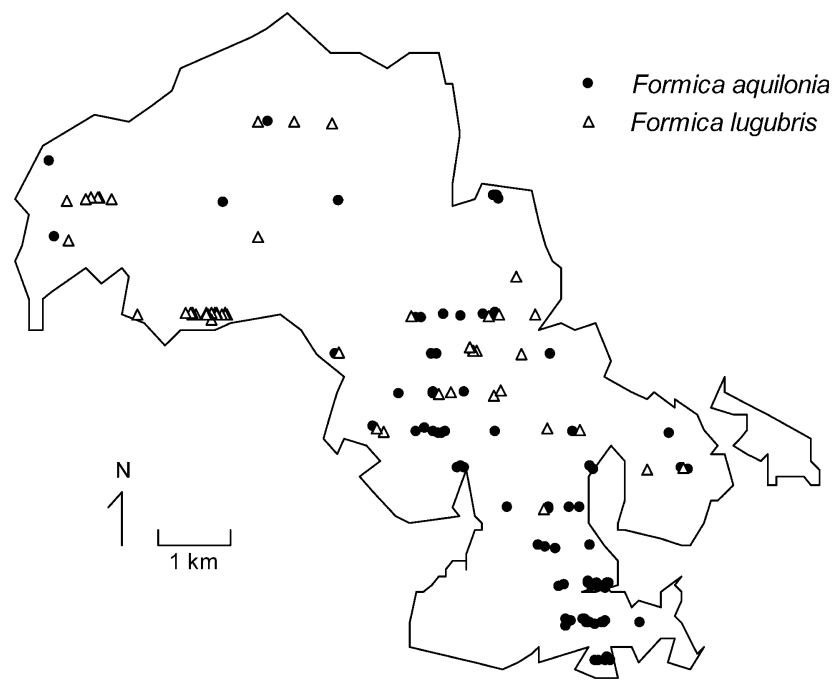

Fig. 2. The distribution of Formica aquilonia and F. lugubris nests along the transects at Abernethy Forest. 


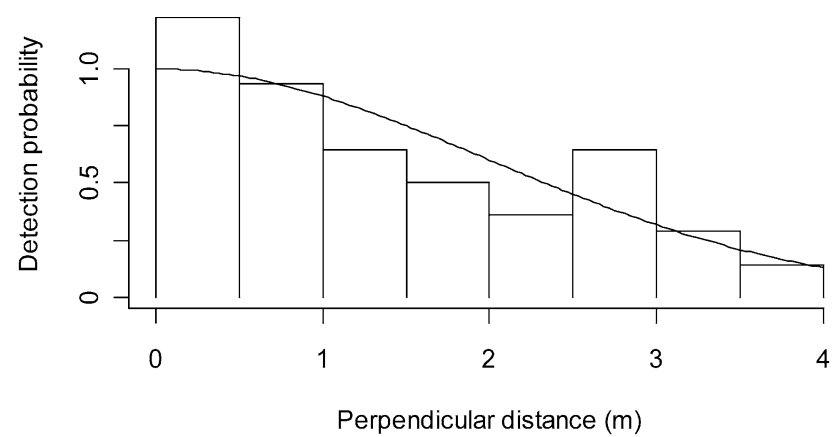

Fig. 3. The frequency distribution of perpendicular distances that wood ants (Formica aquilonia and F. lugubris) nest mounds were from transect lines through Abernethy Forest, and the fitted detection curve. Sample size $=66$.

varied by only $10 \%$ from those reported above. At $25 \mathrm{~m}$, stand type and nest size were both selected by AIC as covariates in the final detection function model, while at $20 \mathrm{~m}$ and fewer, neither covariate was selected.

For the analysis of stand type association, the data were truncated to include only those nests within $20 \mathrm{~m}$ of the transect lines. This meant a loss of $13.5 \%$ of the $F$. aquilonia nests and $10.9 \%$ of the F. lugubris nests. Twenty metres was the largest distance for which stand type was not included as a covariate in the detection function modeling. In addition, within the remaining data set, there was no significant difference for the average distances from the transect line among stand types (Kruskal-Wallis test statistic $=5.54, P=0.14$ ), providing further evidence that detection was similar among the stand types out to this distance, despite differences in the shrub layer composition (Table 1) and height differences of nests amongst stand types. Repeating the analysis at smaller truncation distances produced similar results, although below distances of $10 \mathrm{~m}$, small sample size made results unreliable. Formica aquilonia mounds were mainly found in old open woodland (old-growth) and were absent from wooded bogs and clear-felled areas. Indices for selection (Table 3 ) indicated that $F$. aquilonia avoided the understorey re-initiation stage for building mounds, but showed some association for old-growth woodland, although the $95 \%$ confidence interval in the latter case included zero, so no definitive statement can be made. Formica lugubris mounds were found in areas of wooded bog, pole stage woodland and thickets. They did not occur in old open woodland and clear-felled areas. Indices for selection (Table 3 ) indicated that F. lugubris were associated with stands at stem exclusion, with evidence of avoidance of understorey re-initiation and old-growth, although $95 \%$ confidence interval in the former just included zero.

\section{DISCUSSION}

\section{Estimation of nest mound abundance}

We used a line transect sampling method to investigate red wood ant nest mound density for the first time in this study. This method has several general assumptions which we were able to meet; (1) that all target subjects (nest mounds) on the transect line are detected, (2) that the subjects do not respond to the observer prior to detection, (3) that encounters with the subjects are independent, and (4) that measurements of angles and distances are accurate (Buckland et al., 2001). In several respects, ant nest mounds are ideally suited to transect sampling because they do not move, thereby fulfilling assumptions 1-3. Training, and the use of measurement aids ensures assumption 4 is fulfilled.

Our study found red wood ant densities of 1.13 nests per hectare for $F$. aquilonia and 0.83 for $F$. lugubris. These nest mound densities were similar to those found in Finland, where Punttila (1996) reported 0.8 and 1.7 per hectare for $F$. aquilonia, and 1.9 and 0.1 per hectare for $F$. lugubris in young and old conifer forests, respectively. Values around 1.2 mounds per hectare appear to be typical for total forest areas in Finland (Wuoreninne, 1975), though specific areas can have higher densities; 4-6 nests per hectare for F. aquilonia (Vepsäläinen \& Wuorenrinne, 1978) and 2.6-2.9 nests per hectare for all red wood ants (Domisch et al., 2005). Exceptional densities of over 100 red wood ant nests per hectare can sometimes occur (Vepsäläinen \& Wuorenrinne, 1978). By contrast, Breen (1979) found a much lower density (0.13

TABLE 2. Sample size (within truncation distance of $4 \mathrm{~m}$ ), estimated densitiy (number per hectare), abundance and coefficient of variation (CV) of F. aquilonia and F. lugubris nest mounds at Abernethy Forest, based on the line transect analysis. 95\% CIs are given in brackets.

\begin{tabular}{lcccc}
\hline & Sample size & Density & Abundance & $\%$ CV \\
\hline Both species & 66 & $1.96(1.19-3.22)$ & $7,300(4,400-12,000)$ & 24.8 \\
F. aquilonia & 38 & $1.13(0.74-1.73)$ & $4,200(2,700-6,400)$ & 27.6 \\
F. lugubris & 28 & $0.83(0.32-2.17)$ & $3,100(1,200-8,100)$ & 47.9 \\
\hline
\end{tabular}

TABLE 3. Indices of stand association for F. aquilonia and F. lugubris nest mounds at Abernethy Forest. Positive values indicate association and negative values avoidance. $95 \%$ CIs are given in brackets. Open areas were not included because no nests were found there.

\begin{tabular}{|c|c|c|c|c|}
\hline Stand type & $F$. aquilonia & Sample size & F. lugubris & Sample size \\
\hline Stand initiation & $0.13(-0.59,0.58)$ & 14 & $0.06(-0.39,0.58)$ & 8 \\
\hline Stem exclusion & $-0.20(-0.73,0.29)$ & 13 & $0.42(0.03,0.69)$ & 21 \\
\hline Understorey re-initiation & $-0.62(-1.00,-0.21)$ & 4 & $-0.20(-0.76,0.01)$ & 8 \\
\hline Old-growth & $0.37(-0.19,0.77)$ & 46 & $-0.33(-0.77,-0.07)$ & 12 \\
\hline
\end{tabular}


nests per ha) of F. lugubris in a conifer plantation in Ireland.

Variation in density of nest mounds amongst stand types and transects occurred in our study, and therefore the design of future studies should be carefully considered. The coefficients of variation for nest densities were high for both species in our study (Table 2), particularly for $F$. lugubris, leading to wide confidence intervals. Uncertainty in line transect estimates comes from two sources: estimating the effective strip width, and mean encounter rate (number of nests per transect line divided by line length). In this study, most of the variation was due to the encounter rate component - i.e., due to differences in encounter rate along the different transects. For $F$. aquilonia, $75.2 \%$ of the overall variance in the density estimates came from this source, whilst for F. lugubris it was $95.2 \%$. This percentage would have been even higher had we not used systematic design coupled with the use of the newly-developed overlapping post-stratification encounter rate variance estimator $(\mathrm{O} 2)$ of Fewster et al. (2009), which helped minimize the effect of the observed north-sound gradient in nest density. Encounter rate variation could have been substantially reduced by poststratifying by stand type and hence negating the effect of between-stand type variation in density, but sample size was insufficient. We therefore recommend the systematic parallel design for future surveys, but suggest a higher survey effort together with regular recording of the stand type along the line, so that it will be possible to poststratify estimation by stand type.

Truncating at the distance at which probability of detection was approximately 0.15 led to a truncation point of 4 $\mathrm{m}$ being chosen and around $54 \%$ of the data being excluded from the density analysis. Confirmatory analyses at a wide range of truncation distances gave less than $10 \%$ variation in estimated density, indicating that the results are robust to the choice of truncation, as is typical for line transect studies (Buckland et al., 2001). At the largest truncation distance $(25 \mathrm{~m})$, stand type and nest size were both selected as covariates in the final detection function model. It was not surprising that these factors became more important at larger distances as nest mounds are more obvious when larger or in, for example, more open stand types. Sample sizes of detections are also larger, enabling AIC to select more parameter-rich models. Surprisingly perhaps, at larger truncation distances, the variance of the overall density estimates was larger than at the $4 \mathrm{~m}$ truncation distance chosen. This was because at larger distances, the spike in detections in the first few metres followed by a long tail in detections at larger distances became a prominent feature, and the hazard rate detection function, which is able to fit such a pattern, became the key function selected as the best model by AIC. The intercept of this spiked function was estimated with considerable uncertainty, leading to a greatly increased variance in estimated effective strip width and hence an increase in overall variance. Hence, we believe our decision to follow Buckland et al.'s (2001) recommendation to truncate at a distance at which prob- ability of detection was approximately 0.15 led to more reliable inferences about population density. In our case, this approach led to quite extreme truncation (over 50\% of the observations) and resulted in a truncation distance of $4 \mathrm{~m}$. Future surveys should focus search effort more into the region close to the line (up to approximately four metres). This will reduce the spike in observations within $0.5 \mathrm{~m}$ of the line (Fig. 3), and lead to greater precision in detection function estimation, as well as less sensitivity of results (such as variance) to the chosen truncation distance. We suggest that observers can, for example, leave the transect line to search behind nearby obstacles (such as large trees) so long as the position of the line is known so that distance from nests to line can be accurately measured, and no nests on the line are missed.

\section{Stand type associations}

Our transect survey method was able to identify spatial segregation of the two species, with $F$. aquilonia in the southern part of Abernethy Forest and $F$. lugubris more in the central area (Fig. 2). These distributions were associated with particular stand types; $F$. aquilonia tending to associate with the old-growth stands found mainly in the south and F. lugubris with younger more central stands. These associations concur with the results of a previous study (Punttila, 1996). Formica aquilonia is usually thought to be tolerant of the low light conditions found in young stands (Punttila, 1996). However, we suggest that $F$. aquilonia's tolerance of low light conditions (Punttila, 1996) was not observed because the forest floor in the old-growth woodland at Abernethy Forest has greater irradiance than understorey re-initiation and stem exclusion stands (Parlane et al., 2006). It appears that longterm stability in the old-growth woodland was more important than light conditions.

The patterns of stand type association we found can be attributed to differences in each species' ability to disperse, colonise and compete (Savolainen et al., 1989). Some queens are also dependent on acceptance into a nest of a species of the sub-genus Serviformica to establish a colony because they cannot raise broods on their own (Dekoninck et al., 2010). Formica lugubris disperses further than $F$. aquilonia because of its higher frequency of alate-producing nests, resulting in mating flights and the establishment of a new nest elsewhere, whereas $F$. aquilonia queens often do not have a nuptial flight and may return to the original colony (Rosengren \& Pamilo, 1983). Expansion is through the slow process of budding of nests (Punttila, 1996). Therefore, F. lugubris manages to colonise young forest before $F$. aquilonia, but because $F$. aquilonia is competitively superior, it tends to monopolise older forest, presumably by out-competing any $F$. lugubris (Vepsäläinen et al., 2000). However, in an experiment, Gibb \& Johansson (2011) did not observe a change in the species composition of other ant species when $F$. aquilonia was removed.

The current age structure of the forest and hence the assemblage of ant species present in Abernethy Forest may be attributed to past human use. Much of the southern half of Abernethy Forest, dominated by F. aqui- 
lonia, is ancient native pinewood, which has been relatively undisturbed since 1869 when crofters, who would have grazed livestock in the woods, were removed and the area became a sporting estate (Summers et al., 1997, 2008). Even during the crofting era, the silviculture was a shelterwood system, so that some old trees were always retained as seed trees (Steven \& Carlisle, 1959). Selective felling plus browsing by livestock and the increasing red deer Cervus elaphus (Lönnberg, 1906) population, encouraged for sport shooting, would have inhibited tree regeneration and kept the woodland open and light levels reaching the forest floor high. The northern part of Abernethy Forest, with higher densities of $F$. lugubris, has had a history of more aggressive forestry management. Much was clear-felled during the early $19^{\text {th }}$ century but replanted from 1830 (Summers et al., 1997, 2008). There were also stand replacing fires, followed either by ploughing and replanting or leaving the sites to regenerate naturally. Thus, in the northern half of Abernethy we tended to find $F$. lugubris, some $F$. aquilonia, or no ant nests at all.

Our study suggests that some forest management may have hindered red wood ant persistence. No ant nests were found in clear-cut areas in the northern part of Abernethy (Mondhuie) that was recently (1997-2001) cleared of thickets of lodgepole pine Pinus contorta (Douglas ex Loudon, 1838). Clear-felling is detrimental to red wood ant populations because worker ants lose visual cues for orientation and food sources such as aphids in trees (Rosengren \& Pamilo, 1978; Vepsäläinen \& Wuorenrinne, 1978). It is likely too that prior to clear-felling, the thickets of lodgepole pine would have provided poor habitat for ants owing to the low light levels on the forest floor. Supporting this hypothesis, there was evidence of some ants establishing nests on edges of thickets, including along a cleared ride under a pylon line, where more light was available.

Land preparation techniques also appeared to be associated with low nest mound densities. Nests were notably absent in areas that had been ploughed and planted with Scots pines in the 1970s and 1980s (Clais an Eich, Bogelchynack, Rynettin, Bognacruie and North Abernethy; Fig. 1) (Summers et al., 1997). These areas once had oldgrowth woodland, so we assume they had $F$. aquilonia nests. However, clear-felling and ploughing probably eliminated any nests (Punttila et al., 1994; Domisch et al., 2005). To date, over 30 years after the disturbance, recolonisation by the $F$. aquilonia and $F$. lugubris has been poor, though some $F$. exsecta (Nylander) nests occur in these areas, particularly in North Abernethy (RSPB, unpub. data).

Nest mounds also appeared to be absent from Tore Hill (Fig. 1), that had been burned accidentally in 1920 and then replanted in 1932 (Summers et al., 1997). The stands there are now at the understorey re-initiation stage but are probably still too dense to allow sufficient light and warmth for establishment by ants (Skinner \& Allen, 1996).
To maintain the abundance and diversity of red wood ants, we suggest forest managers need to ensure that the stand characteristics required by each species are provided. It is likely that there will be slow changes in the ant community associated with stand dynamics and previous land use of the forest (Dauber et al., 2006). Minimising the fragmentation of stands and ensuring that plantation woodland is contiguous with old-growth woodland will help the spread of ant species (Punttila, 1996; Hughes, 2005). A time-lag is expected before ants respond to landscape change (Rosengren et al., 1979; Dauber et al., 2006). This is demonstrated by our finding that the areas that were ploughed have not even been colonised by F. lugubris after 30 years. This concurs with a Belgium study where 25 years was insufficient time for all woodland species to establish in new forests (Dekoninck et al., 2008). However, as the forest ages and becomes re-colonised by ants, it is likely that the ant community will gradually become to be dominated by $F$. aquilonia, until the next disturbance episode (Vepsäläinen \& Savolainen, 1994; Punttila et al., 1994).

\section{CONCLUSION}

We suggest that the line transect survey method, based on distance sampling, used in this study was successful in determining red wood ant densities and illuminating stand type associations. However, careful consideration of truncation distances, and therefore the area focused on by observers, is required for future surveys. We recommend that land managers consider a similar methodology when aiming to identify the nest mound density and distribution of other red wood ant communities.

ACKNOWLEDGEMENTS. KMB acknowledges the QEII Technicians' Study Award and Landcare Research NZ Ltd for their support. Scottish Natural Heritage and RSPB staff are thanked for allowing the survey to take place. The ants were identified by P. Harvey, A. and P. Sinclair and RWS. A subset of ant samples was kindly checked by C. Collingwood. The drafts were commented upon by P. Dennis, M. Hancock, K. Vepsäläinen and J. Wilson.

\section{REFERENCES}

Anon. 1995: Biodiversity: The UK Steering Group Report. Vol. 2 - Action Plans. HMSO, London, 324 pp.

Anon. 1999: UK Biodiversity Group. Tranche 2 Action Plans. Vol. IV - Invertebrates. English Nature, Peterborough, 473 pp.

AtLegrim O. 2005: Indirect effects of ant predation (Hymenoptera: Formicidae) on bilberry Vaccinium myrtillus. Eur. J. Entomol. 102: 175-180.

Borchers D.L., BuckLAND S.T. \& ZuCChINI W. 2002: Estimating Animal Abundance: Closed Populations. Springer, Berlin, $314 \mathrm{pp}$.

BREEN J. 1979: Nest sites of Formica lugubris (Hymenoptera, Formicidae) in Irish plantation woods. J. Life Sci. R. Dubl. Soc. 1: 13-32.

Buckland S.T., Anderson D.R.., Burnham K.P., Laake J.L. Borchers D.L. \& Thomas L. 2001: Introduction to Distance Sampling: Estimating Abundance of Biological Populations. Oxford University Press, New York, 432 pp. 
Collingwood C.A. 1979: The Formicidae (Hymenoptera) of Fennoscandia and Denmark. Fauna Entomol. Scand. 8: 110-174.

Dauber J., Bengtsson J. \& Lenoir L. 2006: Evaluating effects of habitat loss and land-use continuity on ant species richness in semi-natural grassland remnants. Conserv. Biol. 20: $1150-1160$.

Dekoninck W., Desender K. \& Grootaert P. 2008: Establishment of ant communities in forests growing on former agricultural fields: Colonisation and 25 years of management are not enough (Hymenoptera: Formicidae). Eur. J. Entomol. 105: 681-689.

Dekoninck W., Hendrickx F., Grootaert P. \& Maelfait J.-P. 2010: Present conservation status of red wood ants in northwestern Belgium: Worse than previously, but not a lost cause. Eur. J. Entomol. 107: 209-218.

Domisch T., FinÉr L. \& JuRgensen M.F. 2005: Red wood ant mound densities in managed boreal forests. Ann. Zool. Fenn. 42: $277-282$.

Fewster R.M., Buckland S.T., Burnham K.P., Borchers D.L., Jupp P.E., LaAke J.L. \& Thomas L. 2009: Estimating the encounter rate variance in distance sampling. Biometrics 65: 225-236.

Fowler S.V. \& MACGARVIN M. 1985: The impact of hairy wood ants, Formica lugubris, on the guild structure of herbivorous insects on birch, Betula pubescens. J. Anim. Ecol. 54: $847-855$.

GibB H. \& Johansson T. 2011: Field tests of interspecific competition in ant assemblages: revisiting the dominant red wood ants. J. Anim. Ecol. 80: 548-557.

Gösswald K. 1989: Die Waldameise. AULA, Wiesbaden, 660 pp.

HAEMIG P.D. 1992: Competition between ants and birds in a Swedish forest. Oikos 65: 479-483.

HAEMIG P.D. 1999: Predation risk alters interactions among species: competition and facilitation between ants and nesting birds in a boreal forest. Ecol. Letters 2: 178-184.

Hughes J. 2005: A Review of Wood Ants in Scotland. A report for Scottish Natural Heritage. Jonathan Hughes Ecological Consulting, $38 \mathrm{pp}$

JACOBS J. 1974: Quantitative measurement of food selection - a modification of the forage ratio and Ivlev's Electivity Index. Oecologia 14: 413-417.

Karhu K.J. \& Neuvonen S. 1998: Wood ants and a geometrid defoliator on birch: predation outweighs beneficial effects through the host plant. Oecologia 113: 509-516.

Kilpeläinen J., Punttila P., Finér L., Niemelä P., Domisch T., Jurgensen M.F., Neuvonen S., Ohashi M., Risch A.C. \& SundSTRÖM L. 2008: Distribution of ant species and mounds (Formica) on different-aged managed spruce stands in eastern Finland. J. Appl. Entomol. 132: 315-325.

Mabelis A.A. 2007: Do ants need protecting? Entomol. Ber. Amst. 67: 145-149.

Marques T.A., Thomas L., Fancy S.G. \& Buckland S.T. 2007: Improving estimates of bird density using multiple covariate distance sampling. Auk 127: 1229-1243.

Mason W.L., Hampson A. \& Edwards C. 2004: Managing the Pinewoods of Scotland. Forestry Commission, Edinburgh, $234 \mathrm{pp}$.

Oliver C.D. \& Larson B.C. 1996: Forest Stand Dynamics. Wiley, New York, 520 pp.
Paivinen J., Ahlroth P., Kaitala V. \& Suhonen J. 2004: Species richness, abundance and distribution of myrmecophilous beetles in nests of Formica aquilonia ants. Ann. Zool. Fenn. 41: 447-454.

Parlane S., Summers R.W., Cowie N. \& van Gardingen P. 2006: Management proposals for bilberry in Scots pine woodland. For. Ecol. Manag. 222: 272-278.

PuntTila P. 1996: Succession, forest fragmentation, and the distribution of wood ants. Oikos 75: 291-298.

Punttila P., Haila Y., Niemelä J. \& Pajunen T. 1994: Ant communities in fragments of old-growth taiga and managed surroundings. Ann. Zool. Fenn. 31: 134-144.

R Development Core Team 2010: $R$ : A Language and Environment for Statistical Computing. R Foundation for Statistical Computing, Vienna, Austria. http://www.r-project.org

Rosengren R. \& PAmilo P. 1978: Effects of timber felling on route fidelity of wood ants. Memor. Zool. 29: 143-155.

Rosengren R. \& Pamilo P. 1983: The evolution of polygyny and polydomy in mound-building Formica ants. Acta Entomol. Fenn. 42: 65-77.

Rosengren R., VepsäläInen K. \& Wuorenrinne H. 1979: Distribution, nest densities, and ecological significance of wood ants (the Formica rufa group) in Finland. O.I.L.B. Bull. SROP (II) 3: 181-213.

SAVOlainen R., VepsäläINEN K. \& WuorenRinNe H. 1989: Ant assemblages in the taiga biome: testing the role of territorial wood ants. Oecologia 81: 481-486.

SkinNer G.J. \& AlLEN G.W. 1996: Ants. Naturalists' Handbooks 24. Richmond, Slough, UK, 83 pp.

Sossai M.F., Zanuncio J.C., Leite H.G., Zanetti R. \& Serrão J.E. 2005: Transects to estimate the number of leaf-cutting ant nests (Hymenoptera: Formicidae) in Eucalyptus urophylla plantations. Sociobiology 46: 667-676.

Steven H.M. \& Carlisle A. 1959: The Native Pinewoods of Scotland. Oliver and Boyd, Edinburgh, $368 \mathrm{pp}$.

Summers R.W., Proctor R., Raistrick P. \& Taylor S. 1997: The structure of Abernethy Forest, Strathspey, Scotland. Bot. J. Scotl. 49: 39-55.

Summers R.W., Wilkinson N.I. \& Wilson E.R. 2008: Age structure and history of stand types of Pinus sylvestris in Abernethy Forest, Scotland. Scand. J. For. Res. 23: 28-37.

Thomas L., Buckland S.T., Rexstad E.A., Laake J.L., Strindberg S., Hedley S.L., Bishop J.R.B., Marques T.A. \& BuRnham K.P. 2010: Distance software: design and analysis of distance sampling surveys for estimating population size. $J$. Appl. Ecol. 47: 5-14.

Vepsäläinen K. \& Savolainen R. 1994: Ant-aphid interactions and territorial dynamics of wood ants. Memor. Zool. 48: 251-259.

VEPSÄLÄINEN K. \& WuORENRINNE H. 1978: Ecological effects of urbanization in mound-building Formica L. species. Memor. Zool. 29: 191-202.

Vepsäläinen K., SAVolainen R., Tiainen J. \& Vilén J. 2000: Successional changes of ant assemblages: from virgin and ditched bogs to forests. Ann. Zool. Fenn. 37: 135-149.

WuoreninNe H. 1975: Über die Notwendigkeit und die Möglichkeiten des Waldameisenschutze in Finnland. Waldhygiene 11: 48-50.

Received March 22, 2011; revised and accepted September 8, 2011 